\title{
COMMENTARY
}

\section{Digitalized service multinationals and international business theory}

\section{Jean-François Hennart}

Tilburg University, Tilburg, The Netherlands; Vienna University of Economics and Business, Vienna, Austria; Politecnico di Milano, Milan, Italy

\section{Correspondence:}

J Hennart, Tilburg University, Tilburg, The Netherlands.

Tel: +31 13 5081831;

e-mail: j.f.hennart@uvt.nl
Received: 2 March 2019

Revised: 3 April 2019

Accepted: 19 May 2019

Online publication date: 12 August 2019

\begin{abstract}
Banalieva and Dhanaraj argue that digital service multinationals (DSMNCs) possess a new category of firm-specific advantage (FSA), the network advantage, and that, contrary to extant theory, they use networks as a mode of governance. I review the business models used by DSMNCs, compare them to non-digital ones, and explore what we can learn about them from extant IB theory. I conclude that network advantages are not a new category of FSAs, that networks are not a mode of governance, and that their use by DSMNCs is well explained by extant theory.
\end{abstract}

Journal of International Business Studies (2019) 50, 1388-1400.

https://doi.org/10.1057/s41267-019-00256-2

Keywords: internalization theory; transaction cost theory; networks; services; digital platforms

The online version of this article is available Open Access

\section{INTRODUCTION}

Banalieva and Dhanaraj address the important and interesting issue of "how digitalization alters internationalization theory's assumptions about the nature of firm-specific advantages [FSAs] and predictions about their governance in cross-border transactions" (page 2). Focusing on digitalized service multinational corporations (DSMNCs), such as Uber, Airbnb, Netflix, Google, and Amazon, they argue that (1) the internationalization of DSMNCs is driven by technology and human capital (see their Figure 1); (2) in contrast to traditional internalization theory, which predicts that "hierarchy would be the most efficient governance to protect core technology FSAs... [while] peripheral technology FSAs can be outsourced..." (page 16), DSMNCs govern the exploitation of their technologybased FSAs not through hierarchy or the market, but instead through networks, which they argue are a third governance structure alongside market and hierarchy; (3) digitalization, because it allows for the capture of strong network effects, results in a new type of FSA/ ownership advantage, the network-based ownership advantage $\left(\mathrm{O}_{\mathrm{n}}\right)$.

To evaluate these claims, I propose to revisit what extant IB theory has said about non-digitalized firms. The goal is to get a better feel for what is truly new with DSMNCs. A first step is to 


\section{Organization of Interdependencies}

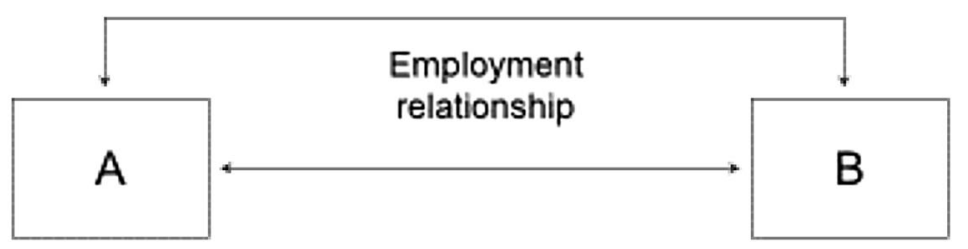

Market exchange

Figure 1 Choice between market and hierarchy

better understand their business models. Since Banalieva and Dhanaraj want to re-assess internalization theory and FSAs, I propose to review these two concepts. I argue that while they are useful, they do not provide a general theory of the existence and extent of a firm's foreign footprint. Furthermore, foreign footprint and foreign sales are two different things. Banalieva and Dhanaraj stress the importance of networks in digitalized business, both as a new type of FSA and as its favored governance structure (see their Figure 1). In fact, network advantages (network externalities) are similar to economies of scale, which have been extensively discussed in the global strategy literature, and the findings of this literature are applicable to DSMNCs. Banalieva and Dhanaraj also see networks as the dominant governance mode for DSMNCs, supplanting markets and hierarchy. I will show that networks are not a third governance structure and not always the best strategy, and that Banalieva and Dhanaraj's Figure 1 overestimates the role of technology and human capital as drivers of the internationalization of service firms while ignoring that of reputation.

\section{TYPES OF DIGITALIZED BUSINESS}

Let us look first at the types of digitalized business discussed by Banalieva and Dhanaraj. Table 1 is a rough and ready categorization of DSMNCs. In the first column I note whether the business model involves businesses (B), consumers (C), or both. The next column describes what is being transacted. The third one lists the fundamental function of the digitized business, and that of its sponsor (the firm that has set up and operates the business). Columns 5 and 6 provide examples of non-digitized and digitized businesses in each category.
In row 1, I place the many firms which seek to put individuals in contact with each other so they can, for instance, share information (Facebook), buy and sell surplus items (eBay, Taobao), rent unused housing space (Airbnb), share rides (BlaBlaCar), and enter into short- or long-term relationships (Tinder, eharmony, Lumen). I call them C2C markets (brokerages) because they function like markets. Their nondigitalized counterparts are flea markets, tourist offices, bulletin boards, marriage bureaus, nightclubs, etc. Both digital and non-digital brokerages reduce search costs by providing a location where information can be shared and/or by setting up a broker who has connections to actors on both sides of the transaction. In digitalized businesses, that location is the website and the broker is the algorithm. In both types of businesses, the value of the brokerage depends on the number and quality of the connections on both sides. Similarly, C2B brokerages put individuals in contact with businesses (examples are job-seeking sites like Indeed.com) and B2B brokerages link small businesses with other small businesses (e.g., Alibaba.com). B2C brokerages (e.g., Booking.com, Expedia) allow businesses to sell goods and services to the public. An important distinction between this category and the next category I call "franchise" is that brokers do not set prices and do not regulate access. ${ }^{1}$

I call digitized businesses in row five "franchises". In contrast to brokerages, service providers in franchises share in the reputation of the platform through their access to the platform trademark. To avoid damage to their reputation, sponsors regulate access and try to control the behavior of service suppliers. Uber, for example, restricts access to its app to drivers who meet its requirements - no serious driving violations, no criminal record, a safe and presentable car. Uber and Lyft suggest to 
Table 1 Types of digitalized service firms

\begin{tabular}{|c|c|c|c|c|c|}
\hline $\begin{array}{l}\text { Business } \\
\text { model }\end{array}$ & Transactions & $\begin{array}{l}\text { Functions } \\
\text { like... }\end{array}$ & $\begin{array}{l}\text { Sponsor } \\
\text { role }\end{array}$ & $\begin{array}{l}\text { Examples of non-digitized } \\
\text { counterparts }\end{array}$ & $\begin{array}{l}\text { Examples of digitized } \\
\text { platforms }\end{array}$ \\
\hline $\mathrm{C} 2 \mathrm{C}$ & $\begin{array}{l}\text { Surplus goods; Relationships; } \\
\text { Private accommodations }\end{array}$ & Markets & Broker & $\begin{array}{l}\text { Flea markets; Marriage bureaus; } \\
\text { Real estate brokers }\end{array}$ & $\begin{array}{l}\text { eBay } \\
\text { Taobao } \\
\text { eharmony }\end{array}$ \\
\hline $\mathrm{C} 2 \mathrm{~B}$ & Jobs & Markets & Broker & $\begin{array}{l}\text { Government job centers; } \\
\text { University placement centers }\end{array}$ & $\begin{array}{l}\text { Job seeking sites } \\
\text { (e.g., Indeed.com) }\end{array}$ \\
\hline $\mathrm{B} 2 \mathrm{~B}$ & Goods and services & Markets & Broker & Brokers & Alibaba.com \\
\hline B2C & Hotel rooms; Transportation & Markets & Broker & Tourist offices; Travel agents & $\begin{array}{l}\text { Booking.com } \\
\text { Expedia }\end{array}$ \\
\hline B2C & Taxi services; Hotel services & Franchises & Franchisor & Fast food; Hotel chains & $\begin{array}{l}\text { Uber } \\
\text { Lyft } \\
\text { Ola }\end{array}$ \\
\hline B2C & Films, music & $\begin{array}{l}\text { Independent } \\
\text { stores }\end{array}$ & Retailer & Brick and mortar stores & $\begin{array}{l}\text { Netflix } \\
\text { Spotify } \\
\text { Amazon }\end{array}$ \\
\hline B2C & Travel & $\begin{array}{l}\text { Captive } \\
\text { stores }\end{array}$ & Retailer & $\begin{array}{l}\text { Airline/railroad offices and ticket } \\
\text { counters }\end{array}$ & $\begin{array}{l}\text { Airline and railroad } \\
\text { own websites }\end{array}$ \\
\hline
\end{tabular}

drivers how they should behave, and cut them from the app if they behave otherwise. ${ }^{2}$ Uber and Lyft set prices. The business model of these taxi platforms is thus similar to McDonalds and other fast-food franchisors who use independent service providers but subject them to a significant degree of behavior control. In contrast to eBay and other $\mathrm{C} 2 \mathrm{C}$ platforms, with episodic use by customers on either side, franchises involve more permanent connections on the service provider side (which is why some public authorities insist Uber and Lyft drivers are in fact employees). ${ }^{3}$

A third category of websites carries out what is fundamentally retailing or distribution. Amazon, Netflix, and Spotify, for instance, resell to consumers goods and services they have bought from others. Lastly, some producers of goods and services have integrated forward into distribution and use electronic platforms to sell their own products. This is the case of airline and railroad-owned websites, our fourth category. In short, our quick overview shows that digitalized businesses are not a homogeneous group and so to understand their logic we must take this into account.

\section{INTERNALIZATION THEORY AND INTERNATIONALIZATION OF DIGITALIZED FIRMS}

Internalization and Transaction Cost Theories Does digitalization, as Banalieva and Dhanaraj claim, affect the assumptions made by internalization theory about the nature of FSAs and the predictions about their cross-country governance? FSAs are a core construct of internalization theory (Narula, 2010, 2014; Verbeke, 2009) and of Dunning's OLI paradigm (e.g., Dunning \& Lundan, 2008), but how useful are they in explaining a firm's foreign footprint and foreign sales?

As Banalieva and Dhanaraj rightly point out, internalization and transaction costs theories seek to explain why some firms undertake value-adding activities abroad. In other words, they aim to predict a firm's foreign footprint. Early proponents of internalization theory argued that to be able to compete with local firms, foreign investors must have some firm-specific advantages (FSAs) over them. ${ }^{4}$ Dunning called them ownership advantages and saw them as consisting of intangibles, such as superior products and processes or valuable trade names. These advantages must be proprietary to the MNE - they must be firm-specific - otherwise they would be freely available to their local competitors, and MNEs would be at a disadvantage, since they usually incur higher costs of doing business outside their own country than local firms (Hymer, 1976; Hennart, 1982; Zaheer, 1995). But having FSAs is not sufficient to have a foreign footprint, as a firm with FSAs could incorporate these advantages in products which it could sell from its home base, i.e., it could serve foreign markets through exports. A second condition is therefore that production in a foreign country must be preferable to exports. In 
other words, the target country must have location advantages (for example abundant natural resources or cheap labor) that justify producing abroad. Lastly, a firm must find it more profitable to have employees exploiting abroad its advantages rather than renting or selling them to independent local firms - in which case the firm would not have a foreign footprint. Hence the third condition is that internalization is the most profitable way to exploit FSAs. This occurs when the market for FSAs is imperfect, and hence their internal transfer is more efficient than their transfer to local firms by market processes.

OLI theory makes intuitive sense, and is eminently testable. Researchers (e.g., Davidson \& McFetridge, 1985; Hennart \& Park, 1994) have found that firms will undertake value-adding activities abroad with their employees if they own valuable firm-specific intangibles which cannot be licensed or franchised, but must instead be incorporated in products manufactured close to the foreign customers - for example because exports would face high transportation costs and trade barriers.

While OLI explains well the foreign direct investments (FDIs) of firms exploiting intangibles, it has problems accounting for other types of FDIs (Hennart, 1991; Asmussen \& Foss, 2014). Firms making backward vertical investments in mineral resources, for example, do not do so to exploit their technological advantages or reputation, but instead to avoid potential holdup problems caused by smallnumber conditions (Stuckey, 1983; Hennart, 1988). ${ }^{5}$ Likewise, vertical forward integration, say by manufacturers into distribution, is not undertaken because manufacturers want to exploit their FSAs at the distribution stage - their FSAs are at the manufacturing stage - but in part because they fear being held up by distributors (Hennart, 2010). A third type of foreign investments undertaken in the absence of FSAs are those made to acquire FSAs, for example the acquisitions of foreign firms to obtain their intangibles. Then, by definition, the goal of the investment is not to exploit FSAs but to acquire them (Hennart, 2012; Asmussen \& Foss, 2014).

To handle these types of FDIs not fitting his original model, Dunning added a new type of FSA/ ownership advantage $\left(\mathrm{O}_{t}\right)$, which he called "advantages of common governance" and which "arise because of multinationality". Narula $(2014,2017)$ sees these $\mathrm{O}_{t}$ advantages as consisting of a firm's ability to coordinate intra-firm activities and to combine its FSAs with assets owned by external actors (see also Narula, Asmussen, Chi \& Kundu,
2019). To the extent that these advantages derive from having successfully internalized the transaction, this is tautological, because this category of FSA can only be observed ex post. In other words, the theory predicts that a firm has internalized because it has $\mathrm{O}_{t}$ advantages, and it tells us we know it has $\mathrm{O}_{\mathrm{t}}$ advantages because it has internalized. This is circular. For OLI to be testable, it must be able to predict internalization ex ante, not ex post. One can test whether the level of a firm's $\mathrm{O}_{a}$ advantages (measured, for example, through its patent stock) affects its FDIs. But it would seem that there is no way to measure a firm's $\mathrm{O}_{t}$ advantages except ex post, after the firm has internalized them. ${ }^{6}$ For this reason, it is my view that the explanatory power of OLI is limited to the case of FDIs made to exploit intangibles.

The transaction cost theory of the MNE (Hennart, 1982, 1991, 2010, 2015b), on the other hand, can account for all investment types. That theory can also throw light on the concept of network, which plays a major role in Banalieva and Dhanaraj's argument. Consider my Figure 1. Assume that there are two agents, A and B, located in two different countries, 1 and 2, and interdependences between them that can be potentially organized at a profit (for example, A has developed a technology that could be used in country 2 , but that needs the local manufacturing facilities controlled by $\mathrm{B}$ to reach customers). There are four ways to organize this interdependence: (1) A can contract with B to license the technology in 2; (2) B can contract with A to obtain a license for the technology; (3) A can hire $B$ as her employee and ask her to set up a manufacturing plant in 2; (4) or B can employ A to implement the transfer of technology to 2 . In cases (1) and (2), the interdependence is organized through the market; in cases (3) and (4) within a firm, in this case an international firm. The question then becomes when and why it might be more profitable to organize an interdependence of that type within an international firm than across an international market.

The answer is that, for a given transaction, there are differences in profitability between coordination by international markets (the bottom line joining A and B) and coordination within international firms using employment contracts (the top line joining $\mathrm{A}$ and $\mathrm{B}$ ) because the main organizing method used in firms (hierarchy) differs from that used in markets (the price system). ${ }^{7}$

Hierarchy, as an organizing method, works by controlling agent behavior through employment 
contracts, while markets do it through the exchange of output. Each organizing method has a comparative advantage in organizing a particular type of interdependence. Consequently, the profits that can be obtained from organizing that interdependence will be maximized if the right type of organizing method is chosen. Whenever hierarchical coordination yields higher profits than coordination through the market, and organizing the interdependence generates net gains, the interdependence will be organized within a firm (Hennart, 1982, 1991, 2010, 2015b). ${ }^{8}$

As I show in Hennart (2015b), this argument can be generalized to all types of interdependencies, and hence can explain all types of FDIs. In contrast to OLI, which shows why interdependencies involving hard-to-market knowledge will lead to the exploitation of that knowledge by its creator through FDI, my theory also explains why the buyers of such knowledge will acquire it through FDI. The same reasons which push A to make B her employee - the inefficiency of the market for technology - also explain why B may want to employ A. Hence, the theory explains both assetseeking and asset-exploiting FDIs. An important implication of this approach is that the rationale for internalization is not only the safeguarding of FSAs by intangible-exploiting firms, but more generally the greater profits that can sometimes be achieved by organizing interdependencies through control of behavior than through exchange of outputs. This explains why the possession of FSAs is not a necessary condition for FDI. It also allows us to explain the governance choices of some digitalized businesses.

An important difference between my approach and standard internalization theory is that my unit of analysis is the interdependency, not the firm. Firms have to deal with many interdependencies, each with its particular characteristics. Some will be more profitably organized within a firm, and some on a market. The size of a firm's foreign footprint is the result of how all international interdependencies facing the firm are organized.

Note also that market failure is not a necessary condition for the emergence of MNEs. Even if organizing an interdependence within an MNE is more profitable than doing it on the market, the benefits of doing so must be higher than the costs. In fact, in some cases, both firm and market coordination will fail. Take the transfer of knowledge during the British industrial revolution. During that period, British firms enjoyed a clear technological advantage over the rest of the world, an advantage similar to that enjoyed by US firms after WW2. At that time, the market for intellectual property was very inefficient, thus justifying the exploitation of knowledge through FDI. Yet this did not happen. Instead, technology was mostly transferred through the emigration of skilled British workers and entrepreneurs, Cockerill for example. One can speculate that this was due to the lack of effective managerial techniques to control foreign subsidiaries (Hennart, 1982: 122-130). So clearly managerial competences matter. Some firms are better than others at organizing internal or external transactions. This will affect the probability they will choose to organize the interdependence internally or externally.

Reputation, embedded in trademarks, can be exploited through outlets operated by independent contractors or through ones manned by employees of the trademark owner. Unless consumers are recurrent and trademark owners can cheaply monitor quality, independent contractors, whose rewards depend on their marketable output, can be expected to increase their profits by reducing the cost of producing output, and hence its quality for example fast-food franchisees may leave the French fries too long under the heat lamp rather than fry a new batch (Brickley \& Dark, 1987). This problem is less prevalent if the outlet is manned by employees, because they do not directly benefit from the outlet's profitability, and hence are more willing to behave in ways that maintain quality. On the other hand, the lack of direct link between their efforts and their rewards means that employees have less incentive to exert effort: they can be expected to shirk. There is therefore a tradeoff between the cost of monitoring employee behavior to avoid shirking and that of controlling quality to avoid free-riding by operators (cheating). ${ }^{9}$

In 1955, when McDonalds started to sell fast food, most trademark owners sold the right to franchise outlets to master franchisees, who in turn sublicensed outlets. Franchisors did not take strong measures to control quality free-riding because, in order to attract master franchises, they gave them substantial autonomy, which resulted in low and uneven quality. Franchisors also earned most of their income from the sale of supplies and equipment to outlets, so they were loath to discontinue poorly performing franchises. Ray Kroc, McDonalds' founder, realized that consistent quality was crucial to the long-term success of a fast-food chain. He chose to directly franchise outlets one-by-one to 
individual franchisees, made them sign detailed contracts with strict quality guidelines, provided them with training, and set up a system of unannounced quality inspections. Payments to McDonalds were not in the form of mark-ups on supplies and equipment, but rather through royalties, which aligned better the interests of franchisor and franchisee. While the franchising practices of its competitors led to systematic quality free-riding by franchisees, and eventually to the demise of their franchise chains, Kroc was able to control this main disadvantage without having to operate outlets with employees, which, while it would have achieved more consistent quality, would have also led to high management costs (Hennart, 1994).

While it may be tempting, following Narula (2014), Gaur, Patnaik, Lee and Singh (2019), and Narula et al. (2019) to call an ability to more efficiently organize interdependencies internally and externally an ownership advantage, this should be resisted for a number of reasons. First, treating these capabilities as ownership advantages results in tautological predictions. Seeing that McDonalds had successfully externalized local fast-food production, Narula et al. (2019) would explain this by McDonalds' external transactional FSA (a superior ability to externalize transactions, or an $\mathrm{O}_{\mathrm{te}}$ ). The problem is that this is not falsifiable since we only know ex post that McDonalds had this advantage. Instead, one should develop a theory of what affects the choice between market and hierarchical governance (i.e., between output incentives and behavior control), identify McDonalds' practices, and, based on the theory, hypothesize how these practices should affect that choice. One can then ascertain whether the predicted effects are actually observed.

In our McDonalds case, transaction cost theory clearly indicates the factors that will lead a trademark owner to choose between using organizational methods heavy on output constraints (loose franchises) versus those heavy on behavior constraints (operating outlets with employees). It predicts that an organizational method that makes it possible to reduce free-riding by franchises without harming their work effort will be more profitable than running the chain with employees. By first understanding the generic dilemma faced by firms which want to exploit a trademark, we are able to predict ex ante how Kroc's innovation of unit-by-unit franchising under strong quality-control guidelines will affect the parameters of this dilemma. Likewise, we can extend our analysis to other contexts, and predict that any technology or system that improves the ability of trademark owners to quickly detect quality lapses by franchisees and to sanction them at low cost will tend to tilt their choice towards the franchising option and away from using employees. The universal reliance on independent drivers by electronic taxi platforms like Uber, Lyft, and Didi can thus be explained by technological advances that reduce the cost to trademark owners of monitoring service quality and of expelling poorly performing drivers. While fast-food franchisors need to make unannounced inspections and, if these clearly show freeriding on quality, initiate legal processes to be able to physically remove signs from the restaurants or expel franchisees from the premises they own, taxi platforms can monitor quality through electronic customer feedback and expel deviant drivers by cutting their access to the app. Everything else constant, such advances favor the use of independent contractors over employees, and hence lead taxi platform firms to have a smaller foreign footprint. ${ }^{10}$ So rather than treating a firm's capacity to handle internal and external transactions as a black-box ownership advantage $\left(\mathrm{O}_{\mathrm{ti}}\right.$ and $\left.\mathrm{O}_{\mathrm{te}}\right)$, I believe it makes more sense to see them as shift parameters that, ceteris paribus, alter a firm's choice of governance mode for a specific interdependence.

The second problem with treating a firm's ability to devise a more effective governance structure as an FSA is that it affects the coherence of the OLI model. While in the OLI model higher ownership advantages (given a high value for internalization advantages) lead to a larger foreign footprint, a higher value of $\mathrm{O}_{\text {te }}$ advantages, on the other hand, will, as we have seen above, lead to a smaller one. This is confusing. In the original OLI model, $\mathrm{O}_{\mathrm{a}}$ advantages lead to a bigger footprint only in the presence of internalization advantages. But what happens when the firm has $\mathrm{O}_{\text {te }}$ advantages? Are these "negative" internalization advantages? Furthermore, and along with Narula (2010), I think that adding countless varieties of $\mathrm{O}$ advantages to the OLI model runs the risk of exceeding its carrying capacity. How many blades can one add to a Swiss Army knife before it loses its purpose?

I do not have the space here for a detailed explanation of why organizing an interdependence using hierarchical processes can, in some cases, be more efficient than doing it through the exchange of outputs (see Hennart, 1982, 1986, 1993). An important point, though, is that coordination through control of behavior and coordination 
through exchange of outputs are the only two organizing methods available. But because each method has both advantages and defects, it usually makes sense to combine them in institutions (Hennart, 1993). Agents rewarded by the sale of output are motivated to maximize it, at the expense of output dimensions difficult to measure (a behavior called cheating, of which free-riding is a type). Inversely, agents rewarded on the basis of their behavior can take advantage of imperfect monitoring of their behavior to work less hard than they promised, i.e., they may be able to shirk. If one makes the reasonable assumption that there are diminishing returns to the exclusive use of either type of organizing method, then it makes sense to combine them in what I have called hybrids (Hennart, 1993, 2013).

To go back to our fast-food example, trademark owners rent their trademarks to independent entrepreneurs, while attempting to constrain their behavior through franchise contracts. These contracts specify rules of behavior that maintain quality (the QSC guidelines) that franchisees must follow to maintain their franchises. Franchise contracts are external hybrids because they use principally output-based incentives - franchisees get to keep most of what they make - but with some quality-preserving hierarchical constraints - the QSC contractual clauses (Hennart, 1993). ${ }^{11}$

Powell (1990), cited by Banalieva and Dhanaraj to support their argument, has advanced that the network is a third organizing method, "neither a market transaction nor a hierarchical governance structure, but a separate, different mode of exchange, one with its own logic". He contrasts networks with market transactions where "the benefits to be exchanged are clearly specified, no trust is required, and agreements are bolstered by the power of legal sanctions". In contrast, he argues that "network forms of exchange... entail indefinite, sequential transactions within the context of a general pattern of interaction. Sanctions are typically normative rather than legal" (Powell, 1990: 301). As examples of networks he cites the web of subcontractors in the construction, publishing, and film industries.

Two points need to be made here. First, Powell's definition of market transactions is a bit of a caricature. Not all market transactions fit his description. Some are recurring, undertaken between parties with a close relationships to each other, guided by social norms rather than written contracts, and enforced through reciprocity or the threat to reputation within a tight social group (Hennart, 2015a; Strange \& Humphrey, 2019). These transactions are market transactions, because parties organize their interdependence through the exchange of outputs, are mostly driven by output incentives, and belong to separate organizations. These criteria - coordination through exchange of outputs between agents who are rewarded by their output at market prices - define market exchange both in theory and law.

Second, the term "network" has been used to describe the structure of a value chain, but also its governance. The two are very different phenomena. The number of firms at one stage of a value chain is sometimes much larger than at the preceding or subsequent stage. This results in a very large number of firms buying from, or selling to, a few firms or even a single firm. This large number of firms is sometimes called a network (Walker, Kogut \& Shan, 1997). For example, one hundred billions of Visa credit card transactions were processed in 2014 in four large data centers located throughout the world on behalf of a handful of credit card brands (e.g., Visa, MasterCard, American Express, JCB, CUP). The signing up of customers, however, is done by a large number a network - of local banks (Wikipedia, 2019). Like all structural networks, the credit card network has arisen because of large differences in minimum efficient scale (MES) between adjacent stages in a value chain. Similarly, brokerages, for instance trading companies, exist because, given the high MES of information collection and processing, it makes sense for buyers and sellers to subcontract this task to a broker. The MES at the upstream stage of fast food - brand building and menu development - is typically larger than that of local food preparation, hence the need for a network of small local outlets, either manned by employees of the trademark-owner, forming an internal network, or by franchisees - an external network. In short, structural networks are configurations, not governance structures. They can be governed by pure hierarchy, by internal hybrids made up of hierarchy plus some market processes, as in the internal network of diversified firms and MNEs (Bartlett \& Ghoshal, 1990; Rugman \& Verbeke, 2003), by external hybrids, which are mostly market but incorporate some hierarchical constraints, as in the case of franchising networks, and by pure market processes, as in the case of markets, electronic or otherwise (Hennart, 2013). Structural networks governed by hierarchy and internal hybrids are 
inside the firm, while those that make use of external hybrids and markets are market transactions. There is no third generic organizing method.

International Footprint Versus International Sales Parallel to the development of theories explaining the existence and size of a firm's foreign footprint, scholars have been interested in explaining the volume of a firm's foreign sales. The two are not the same, since a firm can have extensive foreign sales but zero foreign footprint if it exports all of its production through independent distributors or, alternatively, a very large foreign footprint but no foreign sales if, for example, it mines abroad to procure ores for domestic customers.

There are two fundamental reasons why firms located in one country can profitably sell in another country. The first one is arbitrage, the exploitation of differences between markets separated by distance - differences in input costs (labor, capital, raw materials), but also in tastes, culture, and institutions (Ghemawat, 2007). The second is replication. This strategy, which consists of expanding the domestic sales of a product to foreign markets, makes sense when the optimal scale of production is greater than that supported by the domestic market. This is the case when production processes incur high fixed costs. Then average production costs will decline until MES is reached. If MES is larger than that required to serve domestic customers, the firm will benefit from selling abroad. This strategy is feasible if (1) transportation costs and barriers to exports are low; (2) consumer tastes are homogeneous; (3) the risks of concentrating production in a few locations are tolerable.

Economies of scale exist at the plant level (they lead to exports) and at the firm level. Firm-level economies of scale arise from the presence of fixed costs in generating intangibles. For example, research and development (R\&D) expenditures undertaken to develop a new product or process are fixed costs, which the firm can recoup by selling goods incorporating the new design or process. If the domestic market is too small, the firm will sell abroad. The same argument applies to the building up of reputation through consistent quality, superior service, guarantees, and/or advertising, since, as in the case of innovations, the fixed costs of building a reputation can only be recouped with a sufficient level of sales.

The major difference between plant- and firmlevel economies of scale is that the former require production in a single plant while the latter are compatible with multi-plant operations. Plant-level scale economies are therefore limited by the increase in transportation costs that accompanies the increased concentration of production. By contrast, firm-level economies of scale can be exploited through multiple plants because knowledge and reputation can be cheaply and simultaneously transferred to them. When reaching MES requires a volume of production larger than the domestic market, the firm will sell abroad. If that market is a niche market, the number of domestic customers may be small, and the firm will have to sell abroad almost immediately after birth (Hennart, 2014).

So global strategies consist of selling the same product the same way in all countries. This has a number of limitations. The international exploitation of plant-level scale economies is constrained by transportation costs, and that of both plant- and firm-level scale economies by customer heterogeneity. Some of this heterogeneity is location-based, when where customers live affects their tastes and their ability to use the product as is. Even if there is no need to make product adaptations on a geographical basis, some fraction of the customer base may have needs and interests that are poorly served by a one-size-fits-all product or service offering, and will prefer better-adapted products. These considerations need to be kept in mind when ascertaining the strengths and limitations of DSMNCs.

\section{Internationalization of Service Firms}

What are the drivers of the internalization of service firms? It is generally recognized that consumers face greater uncertainty in assessing the quality of services than that of goods because service quality can only be ascertained ex post, i.e., by consuming it. Firms invest in reputation (through branding) to reduce that uncertainty. Consequently, scholars have found that the international transfer of reputation is an important driver of the internationalization of service firms. Residents of one country who find themselves temporarily or permanently in another have difficulty assessing the quality and reliability of local service providers, and hence are likely to patronize home-country firms that they know and trust. Catering to home-country consumers can give home-country service firms expanding abroad a foothold that allows them to expand to local customers. There is extensive evidence to support this view (e.g., Jones, 1996), for example in the case 
of banks (e.g., Focarelli \& Pozzolo, 2001; Tschoegl, 2005; Galamhussen, Hennart \& Pinheiro, 2016).

\section{COMMENTS ON BANALIEVA AND DHANARAJ'S ARGUMENTS}

\section{Sources of Advantages for Digital Service MNEs}

We now are in a position to assess the arguments made by Banalieva and Dhanaraj. We start with the authors' Figure 1. It shows the governance mode chosen by digital SMNCs to exploit two types of FSAs abroad, those based on human capital, and those based on technology. First, it is not obvious how human-based FSAs differ from technologybased ones. Banalieva and Dhanaraj cite Uber in the section discussing the exploitation of human-based FSAs, but it is unclear how Uber can be described as exploiting human-based FSAs and not technologybased ones, except insofar as its technological advantages are developed by its programmers. It is also not obvious that the technology (i.e., the software) of digital service MNEs is a crucial competitive tool for DSMNCs.

A casual look at the evidence shows that while technology may be necessary for DSMNCs to gain initial market share, it is not sufficient to maintain it. Digital business models appear to be routinely copied by competitors - Taobao replicated eBay and eventually drove it out of China and so did Didi Chuxing with Uber (Solomon, 2016). Bol in Holland, and FNAC in France, successfully compete with Amazon. Missing here, in my view, is the role played by home-country reputation.

\section{Networks As FSAs}

Banalieva and Dhanaraj suggest adding network advantages $\left(\mathrm{O}_{\mathrm{n}}\right)$ to the traditional asset-based $\left(\mathrm{O}_{\mathrm{a}}\right)$ and transaction-based $\left(\mathrm{O}_{t}\right)$ advantages. As we have seen, ownership advantages (FSAs) must be specific to a firm. To avoid tautology, they must also be observable ex ante. Network advantages (also called network externalities) do not seem to fulfill these two conditions. They arise when the attractiveness of a product and service to a new user depends on the number of existing users. For example, the larger the number of buyers and sellers on a C2C brokerage site such as eBay, the more attractive the platform. Network externalities are not only found in electronic platforms, but in other businesses as well, for example credit cards, where the attractiveness of the card to potential users depends on how many sellers will accept it, and to sellers on how many buyers will carry it. If there are network externalities, the firm that is the first to gain market share may have a first mover advantage over followers similar to that gained through scale economies in $R \& D$ or reputation.

So, should network advantages be added to the list of FSAs? Network externalities are not firm specific, they are a characteristic of the industry, or perhaps of the business model within an industry. For instance, any firm that starts a dating site can potentially benefit from network externalities, but they are only firm-specific ex post, in the sense that it is only ex post that we can observe that network externalities benefit a particular firm. ${ }^{12}$ Hence they cannot be antecedents of the foreign footprint or foreign sales volume of a given firm because whether or not they will accrue to a specific firm is not observable ex ante. Paradoxically, while the possession of asset-based $\left(\mathrm{O}_{\mathrm{a}}\right)$ and internalizationbased $\left(\mathrm{O}_{t}\right)$ advantages leads to a greater footprint (given positive values for $\mathrm{L}$ and I advantages), a firm's endowment of $\mathrm{O}_{\mathrm{n}}$ advantages may lead to a smaller one, because the larger the optimal size of the network, the more likely the market can be served from a single location, and hence the smaller the firm's foreign footprint. A firm that sells a global product to a worldwide customer base (Google) is likely to have a smaller foreign footprint than one that must sell locally adapted versions in each country (Uber, Netflix). How much do DSMNCs benefit from network externalities? ${ }^{13}$ As with plant-level scale economies, network externalities are limited by transportation costs. In contrast to communication software like WhatsApp, which can be used worldwide with little adaptation, having the largest network of customers and drivers in a given location, say Boston, does not give Uber an advantage in Bombay, because customers in Bombay cannot use a Boston driver. ${ }^{14}$ If Uber wants to enter Bombay, it will have to build its network there from scratch, putting it at a disadvantage relative to local players if its software is relatively easy to imitate by locals but its business model needs local adaptation, which is apparently the case. Network externalities are also limited by the same factors that limit the exploitation of firm-level scale economies. First, the firm's FSA may be location-bound because the business model is home-country specific (Rugman \& Verbeke, 1992). Google, for example, which dominates the global search market with an $80 \%$ plus market share, has failed to penetrate Korea, where a Korean-designed search engine, Naver, has $70 \%$ of 
the market. One of the reasons is syntax differences between Korean and English, another is subtle preferences in screen layout (Krush, nd). ${ }^{15}$ Differences in the availability of complementary inputs is another limitation (Hennart, 2009). Uber's business model is based in part on moonlighting car owners and a credit-card-based payment system. This poses problems in countries where potential drivers do not own cars and most customers and drivers do not have bank accounts, let alone credit cards (Karnik, 2017). Differences between home- and host-country regulations make the international transfer of some digital business models difficult and sometimes impossible (Pollman \& Barry, 2017). Lastly, although some digitalized business models do not require geographically based adaptation, heterogeneity within a global consumer group makes it possible for rivals to challenge incumbents by focusing on user groups poorly served by a onesize-fits-all offering (Suarez \& Kirtley, 2012).

Network externalities benefit first movers, but as the first mover literature tells us (Lieberman \& Montgomery, 1988), network externalities generate first-mover advantages only if there are high switching costs. At first sight, switching costs in digitalized business appear to be quite low. Yahoo, which was at some time the dominant search engine, was quickly displaced by Google, and so was MySpace by Facebook. Neither users nor drivers do not seem to have difficulty switching between Uber and Lyft, or between Uber and its Indian competitor Ola (Rideshareapp, 2019). The same goes for most e-commerce platforms.

\section{Networks As Governance Structures}

As we have seen, the term "network" has been used to refer to a structural element in a value chain or to a type of governance that is alleged to differ from market and hierarchy. As a structural element, networks arise from differences in MES across stages - as per our earlier credit card example. Digital platforms have often a larger MES than apps and local production units. This results in a pattern of many small developers contributing apps to a platform or many local producers using the platform. There is nothing particular with DSMNCs in that regard. Note, however, that this network structure does not apply to many of the business models listed in Table 1, unless the term network also applies to individuals making relatively infrequent transactions.
"Network" is also meant to describe a governance structure that is supposed to be an alternative to market and hierarchy. Banalieva and Dhanaraj mention Uber. As we have seen, as many firm exploiting a global reputation but having to deliver on the spot services in many locations, Uber has two choices. It can use its own employees, or it can contract with independent drivers. As discussed earlier, it is easier to achieve high quality with employees because they have fewer incentives to cut corners, but because a large number of drivers are required, Uber would experience high monitoring costs and lose in flexibility if it employed them. Independent drivers who get to keep the bulk of what they earn have incentives to work hard and to be flexible, but also to reduce quality: they can be expected to drive too fast, skip on maintenance, and overprice. Uber's software has built-in features that control for some aspects of likely free-riding for example fares are calculated by the software and imposed on drivers, payment in most countries is made directly to Uber, drivers are rated by users, and data are collected on driver ride rejections. It is much easier for Uber and Lyft to discontinue free riders than it is for McDonalds and other franchisors, since all that Uber and Lyft have to do is to cut off driver access to their software (Tomassetti, 2016). ${ }^{16}$ Other forms of driver free-riding, however, have proved harder to control. There have been many instances of accidents caused by careless driving and even assaults on customers (Atchinson Transport Co., 2019). Such events have the potential of putting taxi platforms out of business. Hence, one condition for the use of franchisees is that it is possible to control excessive free-riding on quality. If not, it makes more sense to operate with employees. This is the case with consulting firms that can serve the market with fewer outlets and that would have difficulty contractually specifying quality levels and catching quality lapses before they cause problems. Hence "networks" (i.e., external hybrids) are not a universal solution. DSMNCs will choose this governance structure to exploit their high-technology FSAs when two conditions are met: (1) the business model is characterized by differences in MES across stages and (2) it is more efficient to enlist the initiative of local providers through franchising-like contract and try to tackle the resultant quality debasement problems than to achieve high quality but have to put up with shirking by employees. 


\section{CONCLUSION}

When trying to make sense of supposedly new phenomena, it is important to identify what is really new and what is similar to what we already know. I start by trying to understand what digitized service MNEs (DSMNCs) do. I find that the term covers different business models. Then I take a good look at extant IB theories to see whether they can throw light on these firms. Internalization and transaction cost theories, as well as the literature on the internationalization of service firms, suggest that technology and human capital may not be the main drivers of the internationalization of Internetenabled service firms, that the network configuration is not specific to these firms, that the importance of network externalities may be overstated, and that using the network form of governance (i.e., external hybrids) for local service delivery is only optimal in specific circumstances.

\section{ACKNOWLEDGEMENTS}

I thank Christian Asmussen, Tailan Chi, and Rajneesh Narula for stimulating comments. Part of this research was done while visiting the Research Institute for International Economics and Business at Kobe University. I thank the Institute for its support.

\section{FUNDING}

Open access funding provided by Vienna University of Economics and Business (WU).

\section{NOTES}

${ }^{1}$ Note that the distinction between $\mathrm{C} 2 \mathrm{C}$ and $\mathrm{B} 2 \mathrm{C}$ brokerages is not always sharp. Airbnb is said to be now dominated by multi-unit renters, while eBay admits both businesses and individuals on its website.

${ }^{2}$ Uber tracks drivers' acceptance to take offered rides and their customer ratings, with drivers that rate below 4.6/5 discontinued (Rosenblatt, 2016; Tomassetti, 2016).

${ }^{3}$ While Uber employs many drivers who work part time, Zatz (2016) estimates that full-time drivers (those driving more than 35 hours per week) account for $44 \%$ of total rides. The Paris Uber drivers interviewed by Wentrup, Nakamura, and Ström (2018) reported that they worked an average of 65 hours per week.
${ }^{4}$ Although some still assert this today (e.g., Guillen \& Garcia-Canal, 2009), the assumption that foreign investors must always have a firmspecific advantage over locals overlooks the possibility that foreign investors can acquire FSAs, for example through the acquisition of local firms (Asmussen \& Foss, 2014).

${ }^{5}$ The absence of a connection between intangible-based FSAs and backwards vertical integration is supported by the fact that often the backward integrating firm lets the management of the acquired firm continue to manage the mines and plantations, or in the case of greenfields, uses outside specialist firms to run them.

${ }^{6}$ Dunning and Lundan (2008: 101) define $\mathrm{O}_{t}$ advantages as deriving from the greater ability of MNEs than firms coordinating their activities through the market to shift production, to source globally, to obtain favored access to inputs, to diversify and to reduce risks. However, it is not clear why internal organization always procures such advantages over using international markets (Hennart, 2007).

${ }^{7}$ Internalization does not consist of replacing inefficient external markets by more efficient internal ones. The defining characteristic of a firm is not the replacement of an inefficient system of external prices by a more efficient internal one. While firms make some use of price incentives, in what I have called internal hybrids, this is not what defines them, both legally and theoretically. Instead, the firm is defined by the use of the employment contract under which agents agree to have a boss direct their behavior in exchange for a payment that is not strongly linked to their output (Hennart, 1986, 2013; Masten, 1988).

${ }^{8}$ The goal is not to minimize transaction costs, but to maximize the joint net gains from organizing the interdependence (Hennart, 2015c).

${ }^{9}$ My definition of shirking and cheating is slightly different from that of Chi (1994: 279). He defines shirking as the evasion of a broadly specified obligation, and cheating as that of a narrowly specified one. I define shirking as a violation of the duty of care in an employment contract made possible by imperfect behavior monitoring, and cheating as a violation of the terms of output contracts made possible by imperfect output measurement.

${ }^{10}$ Inversely, Baker and Hubbard (2004) document how the introduction of on-board truck computers has reduced the ability of in-house drivers to shirk and has led manufacturers to rely less on external owner-operators and more on in-house trucking. 
${ }^{11}$ Internal hybrids arise when firms make partial use of output incentives, as in the case of profit centers or piecework (Hennart, 2013).

${ }^{12}$ It has to do with more conventional FSAs, such as how good their algorithms are, or perhaps how carefully their business model has been thought through.

${ }^{13}$ I am indebted to Christian Asmussen for his insights on this topic.

\section{REFERENCES}

Asmussen, C., \& Foss, N. 2014. Competitive advantage and the existence of the multinational corporation: Earlier research and the role of frictions. Global Strategy Journal, 4(1): 49-54.

Atchinson Transport Co. 2019. Reported list of incidents involving Uber and Lyft. www.atchinsontransport.com/blog/ reported-list-of-incidents-involving-Uber-and-Lyft. Accessed April 2, 2019.

Baker, G., \& Hubbard, T. 2004. Contractibility and asset ownership: On-board computers and governance in the U.S. trucking industry. Quarterly Journal of Economics, 119: 1443-1479.

Bartlett, C., \& Ghoshal, S. 1990. The multinational corporation as an interorganizational network. Academy of Management Review, 15(4): 603-625.

Brickley, J., \& Dark, F. 1987. The choice of organizational form: The case of franchising. Journal of Financial Economics, 18(2): 401-420.

Chi, T. 1994. Trading in strategic resources: Necessary conditions, transaction costs problems, and choice of exchange structure. Strategic Management Journal, 15: 271-290.

Davidson, W., \& McFetridge, D. 1985. Key characteristics in the choice of international technology transfer mode. Journal of International Business Studies, 16(2): 5-21.

Dunning, J., \& Lundan, S. 2008. Multinational enterprises and the global economy. London: Edward Elgar.

Focarelli, D., \& Pozzolo, A. 2001. The pattern of cross-border bank mergers and shareholdings in OECD countries. Journal of Banking \& Finance, 25(12): 2305-2337.

Galamhussen, M., Hennart, J.-F., \& Pinheiro, C. 2016. What drives cross-border M\&As in commercial banking? Journal of Banking \& Finance, 72(special issue): S6-S18.

Gaur, A., Patnaik, C., Lee, J., \& Singh, D. 2019. Internalization advantage and subsidiary performance: The role of business group affiliation and host country characteristics. Journal of International Business Studies. https://doi.org/10.1057/ s41267-019-00236-6.

Ghemawat, P. 2007. Redefining global strategy. Boston: Harvard Business School Press.

Guillen, M., \& Garcia-Canal, E. 2009. The American model of the multinational firm and the "new" multinationals from emerging economies. Academy of Management Perspectives, 23(2): 23-35.

Hennart, J.-F. 1982. A theory of multinational enterprise. Ann Arbor: University of Michigan Press.

Hennart, J.-F. 1986. What is internalization? Weltwirtschaftliches Archiv-Review of World Economics, 122(4): 791-804.

Hennart, J.-F. 1988. Vertical integration in the aluminum and tin industries. Journal of Economic Behavior \& Organization, 9(3): 281-300.

Hennart, J.-F. 1991. The transaction cost theory of the multinational enterprise. In C. Pitelis, \& R. Sugden (Eds.), The nature of the transnational firm (pp. 81-116). Routledge: London.
${ }^{14}$ Beyond the fact that its success in Boston will make it able to attract Bostonians visiting or working in Bombay.

${ }^{15}$ Korean, Japanese, and Chinese users prefer the busy screens of local search engines to Google's.

${ }^{16}$ Uber's contract with its drivers allows the company to cut off access for any reason and at any time (Tomassetti, 2016: 11).

Hennart, J.-F. 1993. Explaining the 'Swollen Middle': Why most transactions are a mix of market and hierarchy. Organization Science, 4(4): 529-547.

Hennart, J.-F. 1994. The comparative institutional theory of the firm: Some implications for corporate strategy. Journal of Management Studies, 31(2): 193-207.

Hennart, J.-F. 2007. The theoretical rationale for a multinationality-performance relationship. Management International Review, 47(3): 425-452.

Hennart, J.-F. 2009. Down with MNE-centric theories: Market entry and expansion as the bundling of MNE and local assets. Journal of International Business Studies, 40(9): 1432-1454.

Hennart, J.-F. 2010. Transaction cost theory and international business. Journal of Retailing, 86(3): 257-269.

Hennart, J.-F. 2012. Emerging market multinationals and the theory of the multinational enterprise. Global Strategy Journal, 2(3): 168-187.

Hennart, J.-F. 2013. Internal and external hybrids and the nature of joint ventures. In A. Grandori (Ed.), Handbook of economic organization: Integrating economic and organization theory (pp. 481-500). Cheltenham: Edward Elgar.

Hennart, J.-F. 2014. The accidental internationalists: a theory of born globals. Entrepreneurship Theory and Practice, 38(1): 117-135.

Hennart, J.-F. 2015a. Leveraging Asian institutions to deepen theory: A transaction cost perspective on relational governance. Asian Business and Management, 14(4): 257-282.

Hennart, J.-F. 2015b. Commentary: Why and how can multinational enterprises be value- creating organizations? Journal of World Business, 50(4): 623-626.

Hennart, J.-F. 2015c. A transaction cost theory of the TNC. In S. Lundan (Ed.), Transnational corporations and transnational governance (pp. 25-52). London: Palgrave Macmillan.

Hennart, J.-F., \& Park, Y.-R. 1994. Location, governance, and strategic determinants of Japanese manufacturing investment in the United States. Strategic Management Journal, 15(6): 419-436.

Hymer, S. 1976. The international operations of national firms: A study of direct investment. Cambridge, MA: MIT Press.

Jones, G. 1996. The evolution of international business: An introduction. London: Routledge.

Karnik, M. 2017. Uber in India is fundamentally different from Uber in the West. Quartz India, March 17. https://qz.com/ india/926220/uber-in-india-is-fundamentally-different-fromuber-in-the-west. Accessed Feb 25, 2019.

Krush, A. n.d. Google vs. Naver: Why can't Google dominate search in Korea? Link.assistant.com blog. https://www.linkassistant.com/blog/google-vs-naver-why-cant-Googledominate-search-in-korea. Accessed Feb 24, 2019.

Lieberman, M., \& Montgomery, D. 1988. First mover advantages. Strategic Management Journal, 9(3): 41-58.

Masten, S. 1988. A legal basis for the firm. Journal of Law Economics and Organization, 4: 181-198. 
Narula, R. 2010. Keeping the eclectic paradigm simple. Multinational Business Review, 18(2): 35-50.

Narula, R. 2014. Exploring the paradox of competence-creating subsidiaries: Balancing bandwidth and dispersion in MNEs. Long Range Planning, 47: 4-15.

Narula, R. 2017. Emerging market MNEs as meta-integrators: The importance of internal networks. International Journal of Technology Management, 74(1-4): 214-220.

Narula, R., Asmussen, C., Chi, T., \& Kundu, S. 2019. Applying and advancing internalization theory: The multinational enterprise in the 21 st century. Journal of International Business Studies. https://doi.org/10.1057/s41267-019-00260-6.

Pollman, E., \& Barry, J. 2017. Regulatory entrepreneurship. Southern California Law Review, 90(3): 383-448.

Powell, W. 1990. Neither market nor hierarchy: Network forms of organization. Research in Organizational Behavior, 12: 295-336.

Rideshareapp.com. 2019. How to drive for Uber and Lyft at the same time. https://www.rideshareapp.com/drive-for-uberand-lyft-at-the-same-time. Accessed April 2, 2019.

Rosenblatt, A. 2016. The truth about how Uber's app manages workers. Harvard Business Review. www.hbr.org/2016/04/thetruth-about-how-ubers-app-manages-drivers. Accessed April 1, 2019.

Rugman, A., \& Verbeke, A. 1992. A note on the transnational solution and the transaction cost theory of multinational strategic management. Journal of International Business Studies, 23(4): 761-771.

Rugman, A., \& Verbeke, A. 2003. Extending the theory of the multinational enterprise: Internalization and strategic management perspectives. Journal of International Business Studies, 34(2): 125-137.

Solomon, B. 2016. Uber surrenders in China, will join forces with rival Didi. www.forbes.com/sites/briansolomon/2016/08/01/ uber-ends-billion-dollar-china-fight-makes-peace-with-rivaldidi/\#8afff77296f2. Accessed Feb 24, 2019.

Strange, R., \& Humphrey, J. 2019. What lies between market and hierarchy? Insights from internalization theory and global value chain theory. Journal of International Business Studies. https://doi.org/10.1057/s41267-018-0186-0.

Stuckey, J. 1983. Vertical integration and joint ventures in the aluminum industry. Cambridge, MA: Harvard University Press.

Suarez, F., \& Kirtley, J. 2012. Dethroning an established platform. MIT Sloan Management Review, 53(4): 35-41.

Tomassetti, J. 2016. Does Uber redefine the firm? The postindustrial corporation and advanced information technology. Hofstra Labor and Employment Law Journal, 34: 1-78.

Tschoegl, A. 2005. The Californian subsidiaries of Japanese banks. Journal of Asian Business, 20(2): 59-82.

Verbeke, A. 2009. International business strategy. Cambridge: Cambridge University Press.

Walker, G., Kogut, B., \& Shan, W. 1997. Social capital, structural holes and the formation of an industry network. Organization Science, 8(2): 109-125.

Wentrup, R., Nakamura, R., \& Ström, P. 2018. Uberization in Paris: The issue of trust between a digital platform and digital workers. Critical Perspectives in International Business, 15(1): 20-41.

Wikipedia. 2019. Visa Inc. https://en.wikipedia.org/wiki/Visa_ Inc. Accessed March 1, 2019.

Zaheer, S. 1995. Overcoming the liability of foreignness. Academy of Management Journal, 38(2): 341-363.

Zatz, N. 2016. Is Uber wagging the dog with its moonlighting drivers? www.Onlabor.org/is-uber-wagging-the-dog-with-itsmoonlighting-drivers. Accessed April 1, 2019.

\section{ABOUT THE AUTHOR}

Jean-François Hennart is Professor of International Management emeritus at Tilburg University and visiting professor at Vienna University of Economics and Business and Politecnico di Milano. His Theory of Multinational Enterprise (1982) pioneered the application of transaction cost theory (TCT) to international business. He has continued to focus on the application of TCT to the comparative study of international economic institutions such as multinational enterprises MNEs from developed and emerging markets, family firms, and Born Globals, and to modes of foreign market entry. He is a Fellow of the Academy of International Business and of the European International Business Academy and holds an honorary doctorate from the University of Vaasa. His work in the Journal of International Business Studies, Strategic Management Journal, Global Strategy Journal, Management Science, Organization Science, Journal of Economic Behavior and Organization, and in other top journals, has been cited more than 16,000 times.

Open Access This article is distributed under the terms of the Creative Commons Attribution 4.0 International License (http://creativecommons. org/licenses/by/4.0/), which permits unrestricted use, distribution, and reproduction in any medium, provided you give appropriate credit to the original author(s) and the source, provide a link to the Creative Commons license, and indicate if changes were made.

Publisher's Note Springer Nature remains neutral with regard to jurisdictional claims in published maps and institutional affiliations.

Accepted by Christian Geisler Asmussen, Tailan Chi, and Rajneesh Narula, Special Issue Guest Editors, 19 May 2019. This article has been with the author for one revision and was single-blind reviewed. 